\title{
Correction to: Hsp90 co-chaperones, FKBP52 and Aha1, promote tau pathogenesis in aged wild-type mice
}

Marangelie Criado-Marrero ${ }^{1,2 \dagger}$, Niat T. Gebru ${ }^{1,2 \dagger}$, Danielle M. Blazier ${ }^{1,2}$, Lauren A. Gould ${ }^{1,2}$, Jeremy D. Baker ${ }^{1,2}$, David Beaulieu-Abdelahad ${ }^{1,2}$ and Laura J. Blair ${ }^{1,2,3^{*}}$ (1)

\section{Correction to: Criado-Marrero et al. acta neuropathol com- mun (2021) 9, 65 \\ https://doi.org/10.1186/s40478-021-01159-w}

After publication of this article [1], it is noticed this article contained an error: Figure 4 was incorrect.

The correct Fig. 4 has been provided in this Correction.

The original article has been updated.

The original article can be found online at https://doi.org/10.1186/s40478021-01159-w.

*Correspondence: laurablair@usf.edu

${ }^{\dagger}$ Marangelie Criado-Marrero and Niat T. Gebru have contributed equally to this work

1 USF Health Byrd Alzheimer's Institute, University of South Florida, Tampa,

FL 33613, USA

Full list of author information is available at the end of the article

(c) The Author(s) 2021. This article is licensed under a Creative Commons Attribution 4.0 International License, which permits use, sharing, adaptation, distribution and reproduction in any medium or format, as long as you give appropriate credit to the original author(s) and the source, provide a link to the Creative Commons licence, and indicate if changes were made. The images or other third party material in this article are included in the article's Creative Commons licence, unless indicated otherwise in a credit line to the material. If material is not included in the article's Creative Commons licence and your intended use is not permitted by statutory regulation or exceeds the permitted use, you will need to obtain permission directly from the copyright holder. To view a copy of this licence, visit http://creativecommons.org/licenses/by/4.0/. The Creative Commons Public Domain Dedication waiver (http://creativecommons.org/publicdomain/zero/1.0/) applies to the data made available in this article, unless otherwise stated in a credit line to the data. 


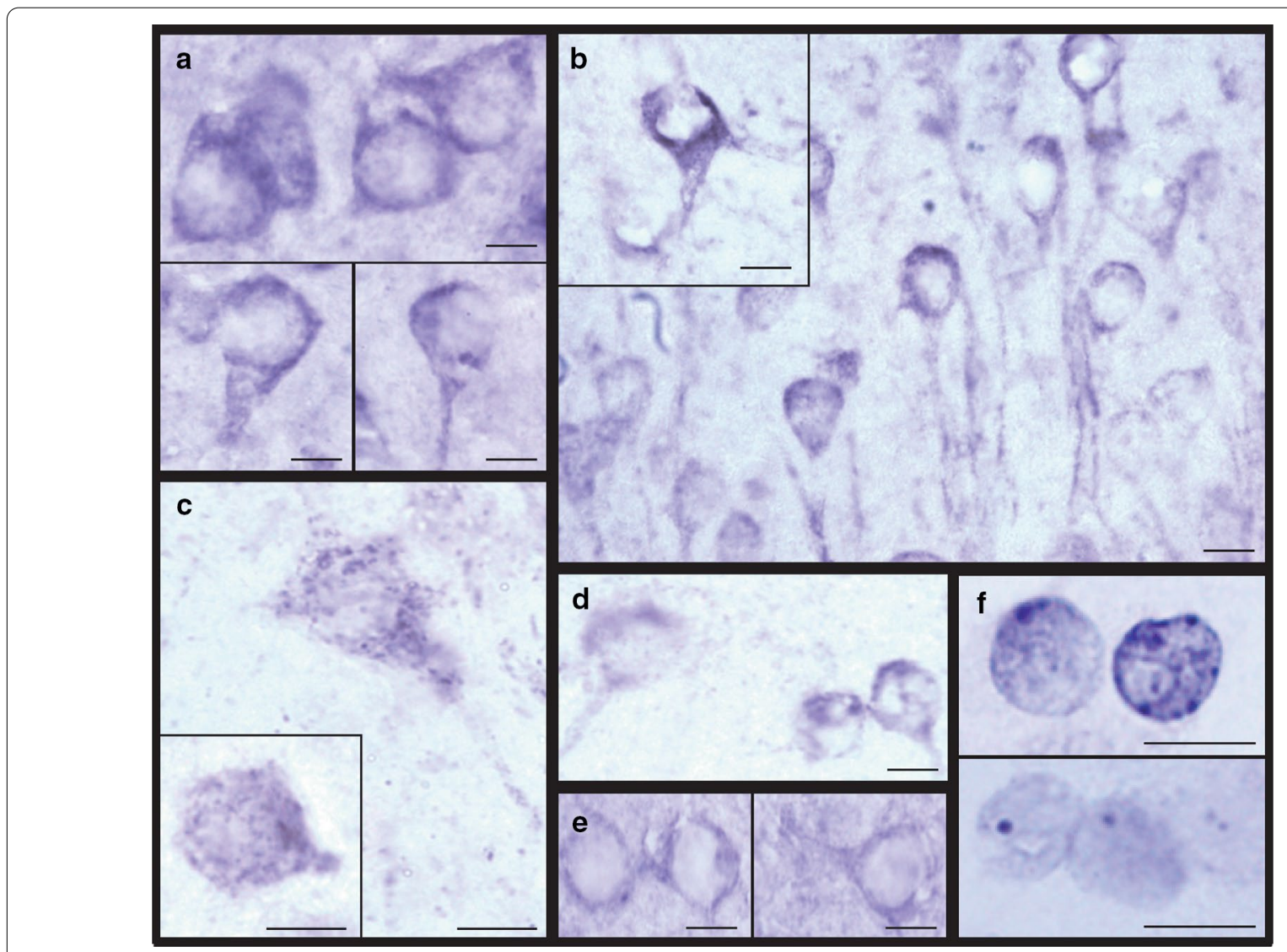

Fig. 4 Examples of tau accumulation in the hippocampus of aged wild-type mice following overexpression of Aha1 or FKBP52. High magnification images $(\times 100)$ were obtained from the hippocampus of a representative animal in the group with the highest tau accumulation. Representative images of tau species and their respective groups are the following: (a) total tau (Dako; AAV9-Aha1), (b) pT231 tau (AAV9-Aha1), (c) AT8 tau (pS202/ T205; AAV9-FKBP52), (d) pS396 tau (AAV9-FKBP52), (e) T22 (AAV9-Aha1), and (f) Gallyas-silver (AAV9-FKBP52). Scale bar represents $10 \mu \mathrm{m}$

\section{Author details}

${ }^{1}$ USF Health Byrd Alzheimer's Institute, University of South Florida, Tampa, FL 33613, USA. ²Department of Molecular Medicine, Morsani College of Medicine, University of South Florida, Tampa, FL 33620, USA. ${ }^{3}$ Research Service, James A Haley Veterans Hospital, 13000 Bruce B Downs Blvd, Tampa, FL 33612, USA.

Published online: 11 May 2021

\section{Reference}

1. Criado-Marrero M, Gebru NT, Blazier DM et al (2021) Hsp90 co-chaperones, FKBP52 and Aha1, promote tau pathogenesis in aged wild-type mice. Acta Neuropathol Commun 9:65. https://doi.org/10.1186/ s40478-021-01159-w

\section{Publisher's Note}

Springer Nature remains neutral with regard to jurisdictional claims in published maps and institutional affiliations. 